\title{
Quality and Physiological Changes of Fresh-cut Kohlrabi
}

\author{
V.H. Escalona, E. Aguayo, and F. Artés ${ }^{1}$ \\ Postharvest and Refrigeration Group, Department of Food Engineering, \\ Technical University of Cartagena, Paseo Alfonso XIII, 48, 30203 Cartagena, \\ Murcia, Spain
}

Additional index words. Brassica oleracea Gongylodes Group, minimally processed, respiratory activity, ethylene emission, browning, microbial counts

\begin{abstract}
Fresh-cut diced (1 $\left.\mathrm{cm}^{3}\right)$ kohlrabi (Brassica oleracea L. Gongylodes Group) 'Kompliment F1' washed with chlorinated $\left(100 \mathrm{mg} \cdot \mathrm{L}^{-1}\right)$ water was stored in modified atmosphere packaging (MAP) up to 14 days at $0^{\circ} \mathrm{C}$. Samples were packed in $35-\mu \mathrm{m}$ oriented polypropylene (PP) bags or in plastic trays heat-sealed with unperforated or perforated (control) PP film. Changes in respiratory rate, ethylene emission rate, microbial growth, color, browning, decay, sugar contents, chemical attributes (soluble solids content, pH, and titratable acidity), and sensory attributes (visual appearance, aroma, flavor, and texture) were monitored. Cutting resulted in an increased $\mathrm{CO}_{2}$ production compared to the whole stem, ranging from 2-fold immediately after cutting, to 8 -fold at day 4 . The equilibrium atmospheres within bags and trays were $6 \% \mathrm{O}_{2}$ plus $13 \% \mathrm{CO}_{2}$, and $13 \% \mathrm{O}_{2}$ plus $8 \%$ to $9 \% \mathrm{CO}_{2}$, respectively. In both MAP treatments, microbial development was delayed compared to air (control). The total aerobic counts were lower than $7.7 \log \mathrm{CFU} / \mathrm{g}$, which has been defined as a recommended limit criteria. No physiological disorders, decay. or off-flavor developed. Therefore, sensory quality attributes were suitable for commercial purposes. However, fresh-cut kohlrabi stored in MAP had slightly better color retention and microbial quality than the control.
\end{abstract}

An increasing demand for kohlrabi from European Nordic countries has induced an expansion of the cultivated area in the Spanish Mediterranean coast. The harvest season for kohlrabi extends from November to March, requiring 50 to $65 \mathrm{~d}$ from seed to optimal maturity (Namesny, 1996), with a yield of $\approx 35$ to $45 \mathrm{t} \cdot \mathrm{ha}^{-1}$ (Maroto, 1995). Depending on the cultivar, kohlrabi may be white, purple, or green and should be harvested when the stem is thinner than $8 \mathrm{~cm}$ so that stems are young and tender and do not require peeling. Quality is enhanced by cool, humid weather, which prevents the edible portion from becoming tough and woody. The edible portion can be eaten raw in salads or cooked in soup or stew.

Weight loss, development of diseases, and increasing toughening are the most important causes of kohlrabi deterioration during cold storage (Namesny, 1996). When kohlrabi is stored with leaves, it has a storage life of only 2 weeks at $0{ }^{\circ} \mathrm{C}$. Storage should be at or near $0^{\circ} \mathrm{C}$ to prevent the development of diseases, mainly bacterial soft rot and black rot. Stored without leaves, kohlrabi can be kept up to 3 months at $0{ }^{\circ} \mathrm{C}$ and $98 \%$ to $100 \%$ relative humidity (RH) to prevent shriveling and toughening (Harden-

Received for publication 26 Dec. 2001. Accepted for publication 3 Nov. 2002. The authors are grateful to CYTED, Project XI.14 for a grant to V.H. Escalona and to Spanish CICYT, Project ALI98-1006, for a research contract to E. Aguayo and for financial support. Thanks are also due to CEBAS-CSIC (Murcia) and to FRUVEG Soc. Coop. (Torre Pacheco, Murcia) for providing facilities and kohlrabi, respectively.

${ }^{1}$ To whom reprint requests should be addressed. Telephone: 34-968-325510; fax: 34-968-325433; e-mail: fr.artes@upct.es burg et al., 1986). Perforated film packaging can be used to reduce moisture loss. Storage at low $\mathrm{O}_{2}$ levels in controlled atmosphere (CA) at an optimum temperature of -1 to $1{ }^{\circ} \mathrm{C}$ during 2 weeks resulted in a reduction of respiratory activity and enabled the control of potential pathogens in whole kohlrabi (Saray, 1994). $\mathrm{CA}$ of $3 \% \mathrm{O}_{2}$ plus $5 \% \mathrm{CO}_{2}$ reduced metabolic activity, extending storage life of kohlrabi without leaves up to 4 months at $0{ }^{\circ} \mathrm{C}$ (Moras and Champon cited by Namesny, 1996).

Demand for fresh-cut vegetables has developed rapidly in recent years in European markets, particularly for new products and institutional consumers. Fresh-cut vegetables are subject to stresses that make them very susceptible to physiological and microbial deterioration, which ends in the loss of quality, due mainly to enzymatic browning. For that reason shelf life of these products rarely exceeds $10 \mathrm{~d}$, even under adequate packaging and chilling conditions (Ahvenainen, 1996; Artés, 2000; Brackett, 1987; Hamza et al., 1996). It is essential to keep the temperature as low as possible throughout the production and distribution chain, with 0 to $5^{\circ} \mathrm{C}$ strongly recommended for better quality and longer shelf life (Ahvenainen, 1996; Artés, 2000; Francis et al., 1999). Shelf life of fresh-cut vegetables can be greatly extended by modified atmosphere packaging (MAP) through its effect on the reduction of respiration and ethylene production, which slows down senescence (Artés, 1996; Gorny, 1997; Huxsoll and Bolin, 1989; Kader et al., 1989; Shewfelt, 1987; Watada et al., 1990).

To the best of our knowledge, studies on fresh-cut kohlrabi have not been reported and, thus, it could be considered a new fresh-cut product. Therefore, the aim of the present work was to study the physiological behavior of diced kohlrabi stems, characterized by the respiratory activity and ethylene emission, as well as the main quality attribute changes throughout 2 weeks of storage.

\section{Materials and Methods}

Preparation of kohlrabi stems. 'Kompliment F1' kohlrabi, a green cultivar, was fieldgrown in Torre Pacheco (Murcia, Spain) and harvested in the middle of November. Each plant was selected in the field, eliminating the soiled and decayed stems. Two hours maximum after harvesting they were transported to the laboratory and stored at $0{ }^{\circ} \mathrm{C}$. The next day they were carefully inspected, selecting only those stems that were free from defects and with similar visual appearance. Plant weight ranged from 550 to $700 \mathrm{~g}$, with stem equatorial and longitudinal diameters of 9.5 to $11 \mathrm{~cm}$ and 7 to $8.5 \mathrm{~cm}$, respectively. Stems were washed in a water solution of $100 \mathrm{mg} \cdot \mathrm{L}^{-1} \mathrm{NaOCl}$ at 5 ${ }^{\circ} \mathrm{C}$ (Ahvenainen, 1996).

Each stem was hand-peeled with a sharp knife to obtain a more uniform color and tender product and cut in dices of $\approx 1 \mathrm{~cm}^{3}$ using a commercial cutting machine (Hallde RG-100, Sweden). Dices were immersed into a $100 \mathrm{mg} \cdot \mathrm{L}^{-1} \mathrm{NaOCl}$ water solution at $5{ }^{\circ} \mathrm{C}$ and $\mathrm{pH} 7.5$ for $1 \mathrm{~min}$ and then drained. These operations were carried out in a clean cold room at $7{ }^{\circ} \mathrm{C}$.

\section{Experiment I. Respiration rate and} ethylene production

Rates of $\mathrm{CO}_{2}\left(\mathrm{mg} \mathrm{CO}_{2} \mathrm{~kg}^{-1} \cdot \mathrm{h}^{-1}\right)$ and $\mathrm{C}_{2} \mathrm{H}_{4}$ emission $\left(\mu \mathrm{L} \mathrm{C}_{2} \mathrm{H}_{4} \mathrm{~kg}^{-1} \cdot \mathrm{h}^{-1}\right)$ were determined by using a closed system (Kader, 1992). Four glass jars each containing three whole stems with leaves, and another four jars each containing $200 \mathrm{~g}$ of kohlrabi dices, were placed in a clean cold room at $0{ }^{\circ} \mathrm{C}$ for $14 \mathrm{~d}$. The increase in $\mathrm{CO}_{2}$ and $\mathrm{C}_{2} \mathrm{H}_{4}$ concentrations were monitored after closing the jars daily for 2 to 3 $\mathrm{h}$. Then gas samples were taken with a plastic syringe from the headspace. In order to avoid $\mathrm{CO}_{2}$ accumulation $(\leq 0.3 \%)$ and to maintain a high RH in the jars, a continuous air flow (3-4 $\mathrm{L} \cdot \mathrm{h}^{-1}$ and $95 \% \mathrm{RH}$ ) with a gas mixing system (Flowboard, Davis, Calif.) was applied (Watada et al., 1996) between each measurement. Respiration rates were determined by using a $0.5-\mathrm{mL}$ gas sample injected in a gas chromatograph (GC) (Shimadzu GC-14B, Tokyo) equipped with a thermal conductivity detector (TCD). The $\mathrm{C}_{2} \mathrm{H}_{4}$ emission was measured with a GC (Hewlett Packard 5730A, Palo Alto, Calif.) equipped with a flame ionization detector(FID) on a 1-mL gas sample.

\section{Experiment II. Modified atmosphere packaging}

Kohlrabi dices were placed into polypropylene trays of $17 \times 11 \times 4 \mathrm{~cm}$ (Plasal-Isap, Alcira, Valencia, Spain) or into bags $(25 \times$ $15 \mathrm{~cm}$ ) containing $250 \pm 5 \mathrm{~g}$ each one. Trays were covered with an antimist, oriented polypropylene (OPP) film of 35- $\mu \mathrm{m}$ thickness and 
heat-sealed (Barket model Befor, France) on the edges. The film permeability at $23{ }^{\circ} \mathrm{C}$ and $75 \%$ RH was $5000-6000 \mathrm{~mL} \cdot \mathrm{m}^{-2} \cdot \mathrm{d}^{-1}$ per atmosphere for $\mathrm{O}_{2}$ and $8000-12000 \mathrm{~mL} \cdot \mathrm{m}^{-2} \cdot \mathrm{d}^{-1}$ per atmosphere for $\mathrm{CO}_{2}$ (data provided by the supplier Plásticos del Segura S.L., Murcia, Spain). Bags were made by using the same heat-sealed film (model IS/300H, Parker). Trays with perforated OPP ( 9 holes of $0.7-\mathrm{mm}$ diameter on $187 \mathrm{~cm}^{2}$ ) were used as control $\left(\leq 0.3 \% \mathrm{CO}_{2}\right.$ and $21 \%$ $\mathrm{O}_{2}$ ). To simulate real commercial practices, including the maximum shelf life and retail sale requirements, a storage period of $14 \mathrm{~d}$ at $0{ }^{\circ} \mathrm{C}$ was applied.

Gas measurements. Gas composition $\left(\mathrm{O}_{2}\right.$, $\mathrm{CO}_{2}$, and $\mathrm{N}_{2}$ ) within packages was monitored during storage by a GC (Perkin Elmer Autosystem, Norwalk, Conn.) equipped with a TCD. For analysis, $0.5-\mathrm{mL}$ gas samples were taken from packages by using a plastic syringe through a silicone septum. The $\mathrm{C}_{2} \mathrm{H}_{4}$ levels were determined by injection of 1-mL gas samples in a GC (Hewlett Packard 5730A, Palo Alto, Calif.) equipped with a FID. Five repetitions were made for each treatment.

Microbiological analysis. Samples to determine microbial growth were taken on days 0 and 14 after processing. In both situations, three samples were used to obtain the mean value of each treatment. A 30-g sample of kohlrabi was blended with $270 \mathrm{~mL}$ of peptone water (Merck) for $1 \mathrm{~min}$ into a sterile stomacher bag (model 400 Bags 6041, Steward Laboratory, London) by using a Colwort Stomacher 400 (Steward Laboratory). Serial dilutions were prepared in peptone water. The following media and incubation conditions were used: plate count agar (PCA; Merck, Darmstadt, Germany) for mesophilic microflora, $48 \mathrm{~h}$ at $30{ }^{\circ} \mathrm{C}$; and potato dextrose agar (PDA, Merck) for yeast and molds, $5 \mathrm{~d}$ at $30^{\circ} \mathrm{C}$. Duplicates were made for each dilution (Luna-Guzmán and Barrett, 2000). All microbial counts were reported as log colony forming units per gram of sample $(\mathrm{CFU} / \mathrm{g})$. Microbial quality was evaluated following the CNERNA-CNRS (1996) and Debevere (1996).

Color measurement. Browning on the kohlrabi dices and juice were measured with a tristimulus colorimeter (Minolta CR-300, Ramsey, N.J.), 8-mm diameter of viewing aperture, using a white plate as reference (Y $=94.3 ; \mathrm{x}=0.3142 ; \mathrm{y}=0.3211$, standard CIE illuminant, $2^{\circ}$ observer). Color was expressed as hue angle $\left(\mathrm{H}^{\circ}=\tan ^{-1} \mathrm{~b}^{*} / \mathrm{a}^{*}\right)$ and chroma $\left[\left(\mathrm{a}^{* 2}\right.\right.$ $\left.\left.+b^{* 2}\right)^{1 / 2}\right]$. Measurements were done on the cut zone of the dices. The juice obtained from the product was placed in a glass tube to measure color after waiting $2 \mathrm{~min}$ for sedimentation of the pulp. This has been previously used to follow the extent of enzymatic browning in apple and pear juices (Sapers and Douglas, 1987), while $\mathrm{L}^{*}$ was the parameter better related with enzymatic browning for lettuce (Castañer et al., 1999).

Chemical evaluation. Dices randomly taken from each sample were squeezed with a commercial turmix blender (Moulinex, Barcelona, Spain). The juice was analyzed for soluble solids content (SSC), $\mathrm{pH}$, and titratable acidity (TA). SSC was measured with a hand refractometer (Atago N1, Tokyo) and expressed as ${ }^{\circ} \mathrm{Brix}$ at $20^{\circ} \mathrm{C}$. The $\mathrm{pH}$ was determined by using a digital $\mathrm{pH}$-meter (Crison 501, Barcelona, Spain). For titratable acidity (TA), $10 \mathrm{~mL}$ of juice was titrated with $0.1 \mathrm{~N} \mathrm{NaOH}$ to an endpoint of $\mathrm{pH} 8.1$ (AOAC, 1984) and expressed as grams of citric acid per liter.

Sugar content. Juice $(20 \mathrm{~mL})$ was frozen at $-70{ }^{\circ} \mathrm{C}$. At the end of the experiment, samples were thawed and centrifuged (1-13 model; Sigma, Germany) at $10,468 g_{\mathrm{n}}$ for $10 \mathrm{~min}$. The supernatant was filtered twice-the first time by using a Sep-Pack Cartridge (Waters, Ireland), and the second with a $0.45-\mu$ m nylon filter (Whatman, Clifton, N.J.). Sugar composition was determined by high-performance liquid chromatography (HPLC) equipped with a refractive index detector (L-7490 model; $\mathrm{Hi}-$ tachi, Tokyo) and a LiChrospher 250-4 $\mathrm{NH}_{2}$ (5 $\mu \mathrm{m})$ column (Merck). A $20-\mu \mathrm{L}$ extract sample was injected using a mobile phase of 85 acetonitrile : 15 water (Merck, Germany) at a $1.5 \mathrm{~mL} \cdot \mathrm{min}^{-1}$ flow.

Sensory evaluation. At the beginning and at the end of cold storage, an informal panel of kohlrabi, evaluated visual appearance, aroma, flavor, and texture. The evaluation was scored based on a nine-point scale $(9=$ excellent; $7=$ good; 5 = acceptable, limit of marketability; 3 = poor; and 1 = extremely poor), adapted from Kader et al. (1973).

Weight loss, decay, and browning. Weight loss was measured in each replicate with a scale (Mettler PC 4400, Switzerland; accuracy of $0.1 \mathrm{~g}$ ). Values were expressed as percentage of the initial fresh weight. Decay and browning were determined subjectively for each replicate using the scale ( $1=$ none $; 2=$ slight $3=$ moderate; $4=$ severe; and $5=$ very severe $)$ adapted from Martínez and Artés (1999). Dices scoring higher than 3 were considered as unacceptable for the consumer.

Statistical analysis. The experiment followed a completely randomized design (n five persons, familiar with sensory properties of

= 5) apart from microbial analysis $(\mathrm{n}=3)$. Statgraphic Plus version 2.1 software was used for analysis of variance (ANOVA) and least significant difference (LSD) test at $P \leq 0.05$.

\section{Results and Discussion}

\section{Experiment I. Respiration rate and ethylene emission}

The respiration rate of diced and whole kohlrabi during cold storage decreased from 32 to 15 and from 16 to $2 \mathrm{mg} \mathrm{CO} \mathrm{kg}^{-1} \cdot \mathrm{h}^{-1}$, respectively, with a faster decrease during the first $4 \mathrm{~d}$ of storage (Fig. 1). Cutting resulted in an increased $\mathrm{CO}_{2}$ production than that for the whole stem, ranged from 2-fold immediately after cutting, to 8 -fold at day 4 . The observed trend agrees with reports for other fresh-cut produce where the rate increased 1.2- to 7 fold, depending on the produce, cutting size, and storage temperature (Ahvenainen, 1996; Artés, 2000; Cantwell, 1992; Varoquaux and Wiley, 1994).

There was little $\mathrm{C}_{2} \mathrm{H}_{4}$ production at $0{ }^{\circ} \mathrm{C}$ in whole and fresh-cut kohlrabi, and an emission rate lower than $0.05 \mu \mathrm{LC}_{2} \mathrm{H}_{4} \mathrm{~kg}^{-1} \cdot \mathrm{h}^{-1}$ was found. This behavior was not expected because $\mathrm{C}_{2} \mathrm{H}_{4}$ emission usually increases following minimal processing associated with the wound response (Ahvenainen, 1996; Artés, 2000; Cantwell, 1992; Varoquaux and Wiley, 1994). However, some studies have reported a slightly higher $\mathrm{C}_{2} \mathrm{H}_{4}$ emission in whole than in fresh-cut tomato at $2{ }^{\circ} \mathrm{C}$ (Artés et al., 1999), and slicing in pear did not increase $\mathrm{C}_{2} \mathrm{H}_{4}$ emission (Rosen and Kader, 1989).

\section{Experiment II. Modified atmosphere packaging}

Gas composition within packages. Steady state atmospheres within unperforated OPP packages of $6 \% \mathrm{O}_{2}$ plus $14 \% \mathrm{CO}_{2}$ for bags, and $13 \% \mathrm{O}_{2}$ plus $8 \%$ to $9 \% \mathrm{CO}_{2}$ for trays (Fig.

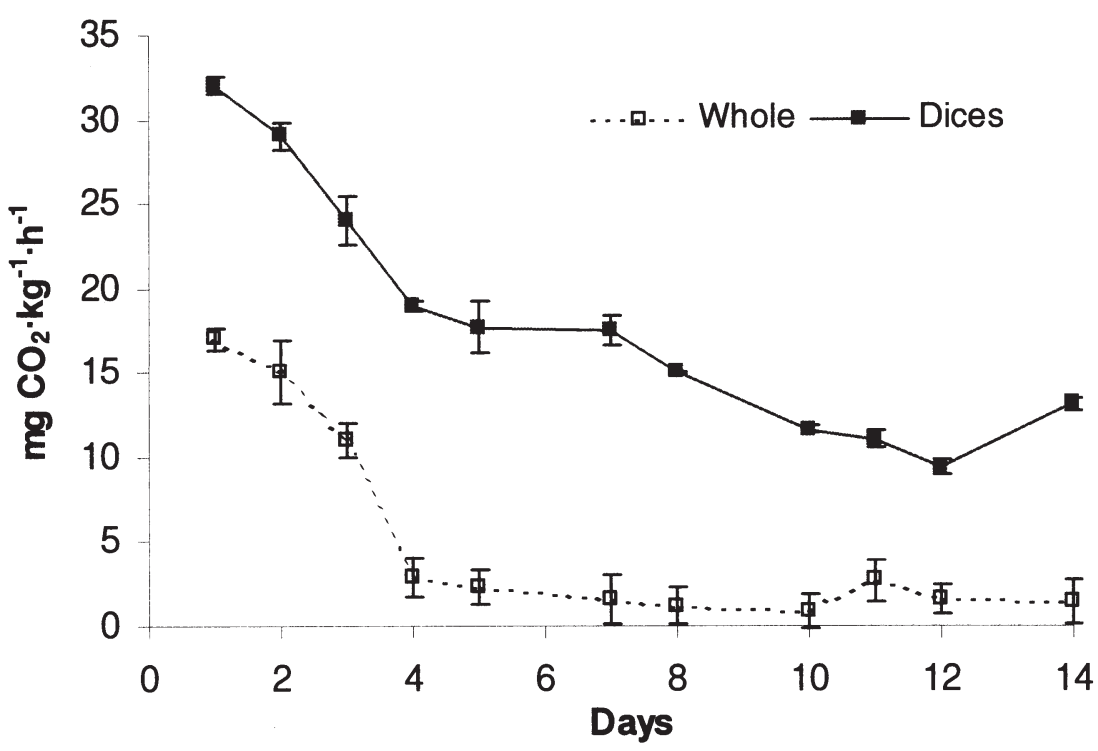

Fig. 1. Respiration rate of whole and fresh-cut kohlrabi for $14 \mathrm{~d}$ at $0{ }^{\circ} \mathrm{C}$ in air. Four replicates per treatment were used. Bars represent standard error $(n=4)$. 
2) were obtained after $4 \mathrm{~d}$. An air atmosphere was obtained in control packages. $\mathrm{C}_{2} \mathrm{H}_{4}$ levels were lower than $0.2 \mathrm{ppm}$ in all treatments throughout the storage period.

Microbiological quality. At harvest total microbial count was lower than $1 \log \mathrm{CFU} / \mathrm{g}$, yeast count was $3.5 \log \mathrm{CFU} / \mathrm{g}$, and mold count was found to be lower than $2 \log \mathrm{CFU} / \mathrm{g}$. After $14 \mathrm{~d}$ of cold storage the TPC increased to 4.3 $\log \mathrm{CFU} / \mathrm{g}$ for the product stored in bags and $4.4 \log \mathrm{CFU} / \mathrm{g}$ for that in trays. In control 6.2 $\log \mathrm{CFU} / \mathrm{g}$ was reached. Mesophilic bacteria counts in fresh-cut vegetables have been reported to be highly variable, ranging from 3 to $9 \log \mathrm{CFU} / \mathrm{g}$. For instance, counts on products analyzed soon after processing ranged from 3 to $6 \log \mathrm{CFU} / \mathrm{g}$, with shredded carrots being the most contaminated and cut iceberg lettuce the least (Nguyen-The and Carlin, 1994). In this experiment, as could be expected, by using moderately elevated $\mathrm{CO}_{2}$ levels microbial growth was retarded (Table 1). The $\mathrm{O}_{2}$ levels of $2 \%$ to $5 \%$ and $\mathrm{CO}_{2}$ levels of $3 \%$ to $10 \%$ combined with refrigeration, have been shown not only to slow down product respiration, also to delay microbial growth, thus retarding physiological aging and extending shelf life (Francis et al., 1999). In fact, $\mathrm{CO}_{2}$, which is soluble in both water and lipid phases, has been reported to be the main factor responsible for the bacteriostatic effect on microorganisms in MAP (Church, 1994).

After cold storage yeast and mold counts were found to be lower than $2 \log \mathrm{CFU} / \mathrm{g}$. Results confirmed that yeasts are generally unaffected by MAP, but trend to decrease during storage, while the growth of molds, as aerobic microorganisms, are commonly delayed (Nguyen-The and Carlin, 1994). The TPC, yeast, and mold counts obtained after $14 \mathrm{~d}$ at $0{ }^{\circ} \mathrm{C}$ (Table 1 ) were always below the recommended limit (7.7 log CFU/g for microbial count, $5 \log \mathrm{CFU} / \mathrm{g}$ for yeast, and 4 $\log \mathrm{CFU} / \mathrm{g}$ for mold) according to CNERNACNRS (1996) and Debevere (1996).

Color. The main factor that affected color changes was the extension of storage. However, the gas composition in MAP treatments had a slight effect on the final product color. After cold storage, decreases in $\mathrm{L}^{*}$ from 68 at harvest to 55 for control and to 62 for OPPpacked kohlrabi dices were found (Table 2). Additionally, an increase of hue angle values for all treatments, without significant differences among them, was found. Also, an increase of chroma values, particularly for the control and, to a lesser extent, for MAP was detected. After $14 \mathrm{~d}$ at $0{ }^{\circ} \mathrm{C}$, MAP treatments delayed the unfavorable color change due to browning.

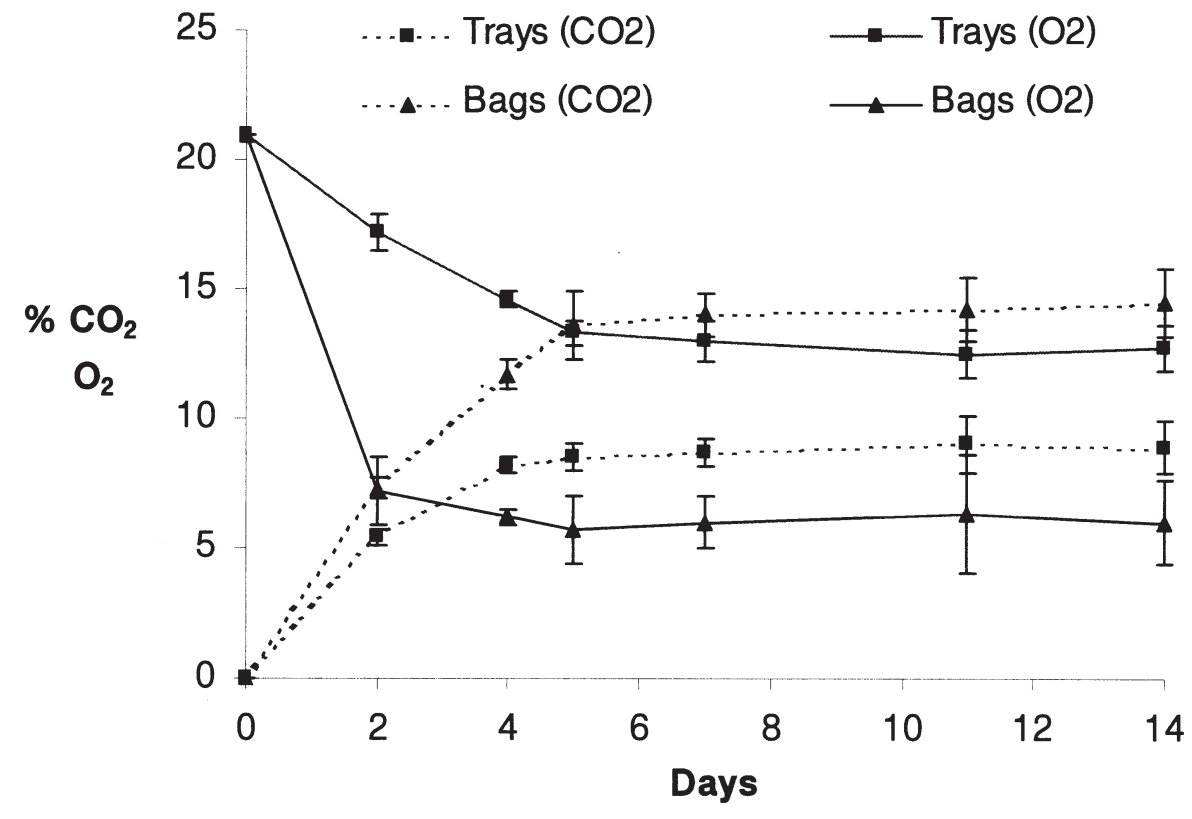

Fig. 2. Changes in $\mathrm{O}_{2}$ and $\mathrm{CO}_{2}$ in fresh-cut kohlrabi in modified atmosphere packaging (MAP) for $14 \mathrm{~d}$ at $0{ }^{\circ} \mathrm{C}$. Five replicates per treatment were used. Bars represent standard error $(\mathrm{n}=3)$.

Table 1. Total plate counts (TPC), yeast, and mold in fresh-cut kohlrabi at harvest and after $14 \mathrm{~d}$ of storage at $0{ }^{\circ} \mathrm{C}$ in modified atmosphere packaging (MAP). Mean values of three replicates are expressed as $\log \mathrm{CFU} / \mathrm{g} \pm$ standard error.

\begin{tabular}{lccc}
\hline Treatments & TPC & Yeast & Mold \\
\hline At harvest & $<1$ & $3.5 \pm 0.0$ & $<2$ \\
After cold storage & & & \\
\hline Control & $6.2 \pm 0.3$ & $<2$ & $<2$ \\
Bags $\left(6 \% \mathrm{O}_{2}+14 \% \mathrm{CO}_{2}\right)$ & $4.3 \pm 0.2$ & $<2$ & $<2$ \\
Trays $\left(13 \% \mathrm{O}_{2}+8 \%\right.$ to $\left.9 \% \mathrm{CO}_{2}\right)$ & $4.4 \pm 0.1$ & $<2$ & $<2$ \\
\hline
\end{tabular}

Particularly, a* values remained significantly higher for kohlrabi in MAP than for the control, meaning better color retention (data not shown). This could be very probably related to low $\mathrm{O}_{2}$ levels in MAP.

The $\mathrm{L}^{*}$ and hue angle of juice from stored kohlrabi dices did not change significantly for any treatment, although chroma was higher at the end of storage with a lower increase for MAP treatments (Table 2). Results indicated that in air storage a process of yellowing occurred. In contrast with results for dices, the juice color was not a parameter suitable for measuring enzymatic browning in fresh-cut kohlrabi. It could be probably due to the fact that the enzymatic browning was only a surface reaction.

Chemical attributes. After cold storage, significant decreases in SSC and AT values were found for all treatments, compared to harvest, due probably to an increase in metabolic activity induced by the minimal processing. However, no changes in $\mathrm{pH}$ values after cold storage were detected (Table 3).

Sugar content. For kohlrabi, glucose and fructose were the predominant sugars, and their concentrations significantly decreased from 2 the end of cold storage in all treatments. Our results agree with those previously reported by Souci et al. (1986). The glucose : fructose ratio was 1 , and it remained stable during the storage period for all the treatments, suggesting a similar pathway of sugar metabolism independent of atmosphere composition and storage time. Picha (1987) also reported no change in that relation for cherry tomato fruit at different ripeness stages. At harvest, an overall glucose: $\mathrm{g} / 100 \mathrm{~mL}$ at harvest to $1.1-1.3 \mathrm{~g} / 100 \mathrm{~mL}$ at

Table 2. Color of dices and juice of kohlrabi at harvest and after $14 \mathrm{~d}$ of storage at $0{ }^{\circ} \mathrm{C}$ in modified atmosphere packaging (MAP). Mean values \pm standard error.

\begin{tabular}{|c|c|c|c|c|c|c|}
\hline \multirow[b]{2}{*}{ Treatments } & \multicolumn{3}{|c|}{ Dices } & \multicolumn{3}{|c|}{ Juice } \\
\hline & $\mathrm{L}^{*}$ & Hue angle & Chroma & $\mathrm{L}^{*}$ & Hue angle & Chroma \\
\hline At harvest & $68.0 \pm 2.2 \mathrm{a}^{2}$ & $104.6 \pm 0.6 b$ & $7.1 \pm 0.7 \mathrm{c}$ & $36.7 \pm 0.7 \mathrm{a}$ & $121.6 \pm 0.6 \mathrm{a}$ & $7.2 \pm 0.3 \mathrm{c}$ \\
\hline \multicolumn{7}{|l|}{ After cold storage } \\
\hline Control & $55.2 \pm 1.9 \mathrm{c}$ & $113.2 \pm 0.9 \mathrm{a}$ & $14.4 \pm 0.8 \mathrm{a}$ & $37.4 \pm 1.0 \mathrm{a}$ & $119.5 \pm 0.8 \mathrm{a}$ & $13.7 \pm 0.5 \mathrm{a}$ \\
\hline $\operatorname{Bags}\left(6 \% \mathrm{O}_{2}+14 \% \mathrm{CO}_{2}\right)$ & $61.9 \pm 1.5 \mathrm{~b}$ & $113.1 \pm 0.8 \mathrm{a}$ & $11.3 \pm 0.7 \mathrm{~b}$ & $35.8 \pm 1.0 \mathrm{a}$ & $120.0 \pm 0.8 \mathrm{a}$ & $11.4 \pm 0.5 b$ \\
\hline Trays $\left(13 \% \mathrm{O}_{2}+8 \%\right.$ to $\left.9 \% \mathrm{CO}_{2}\right)$ & $61.9 \pm 1.5 \mathrm{~b}$ & $114.1 \pm 0.8 \mathrm{a}$ & $12.9 \pm 0.7 \mathrm{ab}$ & $35.9 \pm 1.0 \mathrm{a}$ & $120.6 \pm 0.8 \mathrm{a}$ & $11.3 \pm 0.5 \mathrm{~b}$ \\
\hline
\end{tabular}

${ }^{2}$ Data within a column followed by the same letter are not significantly different $(P<0.05)$ according to LSD $(\mathrm{n}=5)$. 
Table 3. Soluble solids content (SSC), pH, and titratable acidity (TA) in fresh-cut kohlrabi at harvest and after $14 \mathrm{~d}$ of storage at $0{ }^{\circ} \mathrm{C}$ in modified atmosphere packaging (MAP). Mean values \pm standard error.

\begin{tabular}{lccc}
\hline Treatments & SSC & $\mathrm{pH}$ & TA \\
\hline At harvest & $7.6 \pm 0.3 \mathrm{a}^{\mathrm{z}}$ & $7.0 \pm 0.0 \mathrm{~b}$ & $0.62 \pm 0.0 \mathrm{a}$ \\
After cold storage & & & \\
\hline Control & $4.4 \pm 0.3 \mathrm{~b}$ & $6.9 \pm 0.0 \mathrm{~b}$ & $0.42 \pm 0.0 \mathrm{~b}$ \\
Bags $\left(6 \% \mathrm{O}_{2}+14 \% \mathrm{CO}_{2}\right)$ & $4.2 \pm 0.3 \mathrm{~b}$ & $7.2 \pm 0.0 \mathrm{a}$ & $0.31 \pm 0.0 \mathrm{~b}$ \\
Trays $\left(13 \% \mathrm{O}_{2}+8 \%\right.$ to $\left.9 \% \mathrm{CO}_{2}\right)$ & $4.0 \pm 0.3 \mathrm{~b}$ & $7.0 \pm 0.0 \mathrm{~b}$ & $0.35 \pm 0.0 \mathrm{~b}$ \\
\hline
\end{tabular}

${ }^{2}$ Data within a column followed by the same letter are not significantly different $(P<$

$0.05)$ according to LSD $(\mathrm{n}=5)$.

Table 4. Glucose, fructose, and sucrose contents, and glucose : fructose ratio in fresh-cut kohlrabi at harvest and after $14 \mathrm{~d}$ storage at $0{ }^{\circ} \mathrm{C}$ in modified atmosphere packaging (MAP). Mean values are expressed as $\mathrm{g} / 100 \mathrm{~mL}$ juice \pm standard error.

\begin{tabular}{lcccc}
\hline Treatments & Glucose & Fructose & Sucrose & $\begin{array}{c}\text { Glucose : fructose } \\
\text { ratio }\end{array}$ \\
\hline At harvest & $2.0 \pm 0.1 \mathrm{a}^{2}$ & $2.0 \pm 0.1 \mathrm{a}$ & $0.6 \pm 0.0 \mathrm{a}$ & 1.0 \\
After cold storage & & & & \\
$\quad$ Control & $1.3 \pm 0.1 \mathrm{~b}$ & $1.3 \pm 0.1 \mathrm{~b}$ & $0.1 \pm 0.0 \mathrm{~d}$ & 1.0 \\
$\quad$ Bags $\left(6 \% \mathrm{O}_{2}+14 \% \mathrm{CO}_{2}\right)$ & $1.2 \pm 0.1 \mathrm{~b}$ & $1.1 \pm 0.1 \mathrm{~b}$ & $0.4 \pm 0.0 \mathrm{~b}$ & 0.9 \\
$\quad$ Trays $\left(13 \% \mathrm{O}_{2}+8 \%\right.$ to $\left.9 \% \mathrm{CO}_{2}\right)$ & $1.2 \pm 0.1 \mathrm{~b}$ & $1.2 \pm 0.1 \mathrm{~b}$ & $0.2 \pm 0.0 \mathrm{c}$ & 1.0 \\
\hline
\end{tabular}

${ }^{2}$ Data within a column followed by the same letter are not significantly different $(P<0.05)$ according to $\operatorname{LSD}(\mathrm{n}=5)$.

Table 5. Visual appearance, aroma, flavor, texture, and browning of the cut surface in fresh-cut kohlrabi at harvest and after $14 \mathrm{~d}$ of storage at $0{ }^{\circ} \mathrm{C}$ in modified atmosphere packaging (MAP). Mean values \pm standard error.

\begin{tabular}{|c|c|c|c|c|c|}
\hline Treatments & $\begin{array}{c}\text { Visual } \\
\text { appearance }\end{array}$ & Aroma & Flavor & Texture & $\begin{array}{l}\text { Browning of the } \\
\text { cut surface }\end{array}$ \\
\hline At harvest & $8.0 \pm 1.2 \mathrm{a}^{\mathrm{z}}$ & $2.0 \pm 0.7 b$ & $9.0 \pm 0.6 \mathrm{a}$ & $8.5 \pm 0.8 \mathrm{a}$ & $1.0 \pm 0.0 \mathrm{a}$ \\
\hline \multicolumn{6}{|l|}{ After cold storage } \\
\hline Control & $5.0 \pm 0.9 \mathrm{~b}$ & $7.5 \pm 0.5 \mathrm{a}$ & $7.0 \pm 0.4 \mathrm{~b}$ & $6.3 \pm 0.6 b$ & $1.7 \pm 0.2 \mathrm{a}$ \\
\hline Bags $\left(6 \% \mathrm{O}_{2}+14 \% \mathrm{CO}_{2}\right)$ & $6.1 \pm 0.9 b$ & $7.5 \pm 0.5 \mathrm{a}$ & $6.8 \pm 0.4 b$ & $6.8 \pm 0.6 \mathrm{ab}$ & $1.0 \pm 0.1 \mathrm{a}$ \\
\hline Trays $\left(13 \% \mathrm{O}_{2}+8 \%\right.$ to $\left.9 \% \mathrm{CO}_{2}\right)$ & $6.0 \pm 0.9 b$ & $7.5 \pm 0.5 \mathrm{a}$ & $7.0 \pm 0.4 \mathrm{~b}$ & $6.0 \pm 0.6 \mathrm{~b}$ & $1.2 \pm 0.1 \mathrm{a}$ \\
\hline
\end{tabular}

fructose ratio of 0.7 in 12 blackberry cultivars was found while it was about 3 in apples and pears (Wrolstad etal., 1980). Sucrose was present in a low concentration at harvest $(0.6 \mathrm{~g} / 100$ $\mathrm{mL}$ ) and decreased more in control and tray treatments after cold storage (Table 4). This decrease could be related to a higher metabolic activity of control compared to MAP. Probably this sugar was the substrate used for the vegetable to maintain the glucose : fructose ratio. Consequently, in kohlrabi, changes in sucrose levels during cold storage could be a good indicator of senescence.

Sensory attributes. Compared to scores at harvest significant decreases were detected in visual appearance, aroma, and flavor at the end of cold storage (Table 5). However, the levels were still acceptable for commercial purposes. For fresh-cut lettuce, Hamza et al. (1996) reported that $10 \%$ or more $\mathrm{CO}_{2}$ reduced enzymatic browning due to wounding and improved visual quality. An accumulation of aroma inside the packages could be responsible for the high score of this parameter after storage. All treatments induced a loss of flavor, probably due to the decreases in SST and TA. Changes in texture were similar between treatments, probably due to high $\mathrm{RH}$ that reduced water loss in dices. Consequently, use of MAP with moderate $\mathrm{O}_{2}$ and $\mathrm{CO}_{2}$ concentrations could be useful for maintaining sensory quality of fresh-cut kohlrabi.

Water loss, decay, and browning. Weight loss was lower than $0.1 \%$ at the end of cold storage for all treatments. Neither physiological disorders nor decay were detected, although a slight browning on the cut surface for control was found, without differences among treatments (Table 5). The positive effect of MAP in avoiding weight loss and inhibiting oxidative reactions has been reported for a number of fresh-cut vegetables (Huxsoll and Bolin, 1989).

\section{Conclusions}

Whole and fresh-cut kohlrabi stored $14 \mathrm{~d}$ at $0{ }^{\circ} \mathrm{C}$ have a low to moderate nonclimacteric respiratory activity behavior and very low $\mathrm{C}_{2} \mathrm{H}_{4}$ production.

After $14 \mathrm{~d}$ at $0{ }^{\circ} \mathrm{C}$, dices stored under all treatments have a quality higher than acceptable for commercial purposes, showing neither chilling or $\mathrm{CO}_{2}$ injuries nor decay.

A modified atmosphere of $6 \% \mathrm{O}_{2}$ plus $14 \% \mathrm{CO}_{2}$ at $0{ }^{\circ} \mathrm{C}$ enhances chemical and sensory quality and decreases microbial count in comparison to control. This atmosphere also is able to inhibit browning on the surface of kohlrabi dices.

\section{Literature Cited}

Ahvenainen, R. 1996. New approaches in improving the shelf life of minimally processed fruits and vegetables. Trends Food Sci. Technol. 7 (June):179-186

AOAC. 1984. Official methods of analysis. 14th ed. Assn. Offic. Anal. Chem., Virginia.
Artés, F. 1996. Envasado de productos hortofrutícolas en atmósfera modificada. Jornada Proyectos I+D de la UE sobre Aplicaciones de Nuevas Tecnologías a Alimentos Vegetales. Proyecto Flair-Flow. Madrid.

Artés, F., M.A. Conesa, S. Hernández, and M.I. Gil. 1999. Keeping quality of fresh-cut tomato. Postharvest Biol. Technol. 17:153-162.

Artés, F. 2000. Productos vegetales procesados en fresco, p. 127-141. In: M. Lamúa (ed.), Aplicación del frío a los alimentos. Mundi-Prensa, Madrid, Spain.

Brackett, R.E. 1987. Microbial consequence of minimally processed fruits and vegetables. J. Food Quality 10:195-206.

Cantwell, M. 1992. Postharvest handling systems: Minimally processed fruits and vegetables, $\mathrm{p}$. 277-282. In: A.A. Kader (ed.). Postharvest technology of horticultural crops. Univ. of California Publ. 3311.

Castañer, M., M.I. Gil, M.V. Ruíz, and F. Artés. 1999. Browning susceptibility of minimally processed baby and romaine lettuces. Eur. Food Res. Technol. 209: 52-56.

Church, N. 1994. Developments in modified-atmosphere packaging and related technologies. Trends Food Sci. Technol. 5 (Nov.):345-352.

CNERNA-CNRS. 1996. Produits de la IVe gamme, p. 73-98. In: J.L. Jouve (ed.). La Qualité Microbiologique des Aliments (maitrise et criteres). Polytechnica, Paris, France.

Debevere, J. 1996. Criteria en practische methoden voor de bepaling van de houdbaarhei dsdatum in the etikettering, p. 37-64. In: G. Temmerman, G. Cremer, M. Thyssen, and J. Devebere (eds.). Etikettering, houdbaarheid en bewaring (voedingsmiddelen en recht 2), Die Keure, Brugge, Belgium. 
Francis, G.A., C. Thomas, and D. O'Beirne. 1999. The microbiological safety of minimally processed vegetables. Intl. J. Food Sci. Technol. 34:1-22.

Gorny, J.R. 1997. A summary of CA and MAP requirements and recommendations for fresh-cut (minimally processed) fruits and vegetables, $\mathrm{p}$. 30-33. In: J.R. Gorny (ed.). Fresh-cut fruits and vegetables and MAP. CA '97 Proc. 5. Univ. of California.

Hamza, F., F. Castaigne, C. Willemot, G. Doyon, and J. Makhlouf. 1996. Storage of minimally processed romaine lettuce under controlled atmosphere. J. Food Quality 19:177-188.

Hardenburg, R.E., A.E. Watada, and C.Y. Wang. 1986. The commercial storage of fruits, vegetables, and florist and nursery stocks. USDA Hdbk. 66.

Huxsoll, C.C. and H.R. Bolin. 1989. Processing and distribution alternatives for minimally processed fruits and vegetables. Food Technol. 43(2):124-128.

Kader, A.A., W.J. Lipton, and L.L. Morris. 1973. Systems for scoring quality of harvested lettuce. HortScience 8:408-409.

Kader, A.A., D. Zagory, and E.L. Kerbel. 1989. Modified atmosphere packaging of fruits and vegetables. Crit. Rev. Food Sci. 28:1-27.

Kader,A.A. 1992. Methods of gas mixing, sampling, and analysis, p. 93-95. In: A.A. Kader (ed.). Postharvest technology of horticultural crops. Univ. of California Publ. 3311.

Luna-Guzmán, I., and D.M. Barrett. 2000. Comparison of calcium chloride and calcium lactate effectiveness in maintaining shelf stability and quality of fresh-cut cantaloupes. Postharvest Biol. Technol. 19: 61-72.

Maroto, J.V. 1995. Colirrábano, p. 43-44. In: J.V. Maroto (ed.). Horticultura Herbácea Especial. Mundi-Prensa, Madrid Spain.

Martínez, J.A. and F. Artés. 1999. Effect of packaging treatments and vacuum-cooling on quality of winter harvested 'Iceberg' lettuce. Food Res. Intl. 32:621-627.

Namesny, A. 1996. Colirrábano, p. 131-134. In: A. Namesny (ed.). Postrecolección de Hortalizas. Horticultura II.

Nguyen-The, C. and F. Carlin. 1994. The microbiology of minimally processed fresh fruits and vegetables. Crit. Rev. Food Sci. 34:371-401.

Picha, D.H. 1987. Sugar and organic acid content of cherry tomato fruit at different ripening stages. HortScience 22:94-96.

Rosen, J.C. and A.A. Kader. 1989. Postharvest physiology and quality maintenance of sliced pear and strawberry fruits. J. Food Sci. 54:122-124.

Sapers, G.M. and F.W. Douglas. 1987. Measurement of enzymatic browning at cut surface and juice of raw apple and pear fruits. J. Food Sci. 52:1258-1262.

Saray, T. 1994. Controlled atmosphere storage of vegetables: The possibilities. Food Technol. Intl. Europe:67-73. (Abstr.)

Shewfelt, R.L. 1987. Quality of minimally processed fruits and vegetables. J. Food Quality 10:143-156.

Souci, S.W., W. Fachmann, and H. Kraut. 1986. Food composition and nutrition tables. 3rd ed. Deutsche Forschungsanstalt für Lebensmittelchemie, Garching b. München.

Varoquaux, P. and R.C. Wiley. 1994. Biological and biochemical changes in minimally processed refrigerated fruits and vegetables, p. 226-268. In: R.C. Wiley (ed.). Minimally processed refrigerated fruits and vegetables. Chapman and Hall, New York.

Watada, A.E., K. Abe, and N. Yamuchi. 1990. Physiological activities of partially processed fruits and vegetables. Food Technol. 44 (5):116-122.

Watada, A.E., P.Ko. Nathanee, and A.M. Donna. 1996. Factors affecting quality of fresh-cut horticultural products. Postharvest Biol. Technol. 9:115-125.

Wrolstad, R.E., J.D. Culbertson, D.A. Nagaki, and C.F. Madero. 1980. Sugars and nonvolatile acids of blackberries. J. Agr. Food Chem. 28: 553-558. 